\title{
EXPLOITATION RATE BEFORE AND AFTER MORATORIUM IN FISHERIES MANAGEMENT AREA 714, 715, AND 716 FISHERMEN FISHING GROUND IN BITUNG, NORTH SULAWESI OF INDONESIA
}

\author{
Asia*, Alauddin Muhammad Hery Riyadi, Santoso Heru, Manengkey Jenny I, \\ Arifin Muhammad Zainul, Mulalinda Palehel \\ Marine and Fisheries Polytechnic of Bitung, Indonesia \\ *E-mail: sachessaches72@gmail.com
}

\begin{abstract}
Indonesia's Minister of Marine Affairs and Fisheries Regulation No. 57 of 2014 concerning the second amendment to the Minister of Marine Affairs and Fisheries Regulation No. 30 of 2012 concerning Catch Fisheries Business in the territory of the Republic of Indonesia fisheries management, stated Ministerial Regulation article 37 regarding transshipment is abolished. The abolition affected fishing vessels. It reduced fishing vessels operating in the fisheries management area. Therefore, it reduced pressure on fish resources, especially Cakalang fish in the fishing ground. The formulation of the problem in this research was: what is the exploitation rate of Cakalang fish (Katsuwonus pelamis) on FMA 714, 715, and 716 before and after the moratorium. The purpose of this study was to examine the exploitation rate of Cakalang fish (Katsuwonus pelamis) on FMA 714, 715 and 716 before and after the moratorium. Primary data pre-moratorium collection was conducted in 2013. Post moratorium primary data collection was conducted in 2018. The data were analyzed utilizing the FISAT II windows version. Research result exhibited the following result: FMA 714 exhibited $E=0.63$ before the moratorium and $E=0.54$ after the moratorium. FMA 715 exhibited $E=0.69$ before the moratorium and $E=0.57$ after the moratorium. FMA 716 exhibited $\mathrm{E}=0.60$ before the moratorium and $\mathrm{E}=0.54$ before the moratorium.
\end{abstract}

\section{KEY WORDS}

Fisheries management area, Cakalang fish, FISAT II.

Bitung City, North Sulawesi province, became one of the major producers of fisheries commodities in Indonesia. It is the largest tuna producer in Indonesia in 2016 by conducting fishing activity in the Sulawesi Sea, Maluku Sea, and the Pacific Ocean (2017 Bitung PPS).

The Decree of the Ministry of Marine Affairs and Fisheries No. 32 of 2010 stated that Bitung City is one of the minapolitan region and catch fisheries industrialization in Indonesia. Bitung is located in the Lembeh Strait facing the Sulawesi Sea and the Pacific Ocean. This strategic location provides Bitung an opportunity to become one of the centers of regional economic activity in Eastern Indonesia.

Bitung City is called Cakalang City, Harbor City, and Industrial City. Bitung City is a port city in North Sulawesi Province, which is also the largest fish producers. It supplies fish consumption in North Sulawesi province. The remaining products are exported in the form of frozen fish or canned fish. Industrial plants are generally found in Bitung City. Around 70 percent of industrial activity in North Sulawesi is concentrated in Bitung City, which is largely an export-oriented fish processing industry (Mulatsih, 2009).

Cakalang fish migrates from the waters of Eastern Indonesia to the Western Pacific Ocean, namely to the waters of Zamboanga and the north of Papua New Guinea. Cakalang fish can spread vertically up to hundreds of meters below the surface of the water. The distribution of fish in tropical waters is strongly influenced by the thermocline layer (Laevestu and Hela, 1970). Cakalang fish is a pelagic fish that forms a group (schooling). Cakalang individuals in a school are in the relatively same size. Larger fish are usually in the deeper layers with smaller schooling. Smaller fish are usually near the surface of the water with larger schooling. 
The fishing ground in Bitung consists of FMA (Fisheries Management Area) 714, 715, and 716, as well as FMA 717 (DKP, Kota Bitung 2017) and Samudra Bitung Port (PPS) 2017. The regulation of the Minister of Marine Affairs and Fisheries number 182014 stated that FMA 714 covers the waters of the Tolo Bay and the Banda Sea. FMA 715 covers the waters of the Tomini Bay, Maluku Sea, Halmahera Sea, Seram Sea, and Berau Bay. FMA 716 covers the waters of the Sulawesi Sea and Northern Seas of Halmahera Island. FMA 717 covers the waters of the Pacific Ocean and the northern part of Halmahera Island.

The Minister of Marine Affairs and Fisheries Regulation No. 57 of 2014 concerning the second amendment to the Minister of Marine Affairs and Fisheries Regulation No. 30 of 2012 concerning catch Fisheries Business in the territory of the Republic of Indonesia fisheries management, abolished the Minister of Marine Affairs and Fisheries Regulation article 37 regarding transshipment.

The abolition of this article affects fishing vessels carrying catches to the port or ashore, reduced the number of vessels operating in the fisheries management area. Reduced vessels operating in the fisheries management area indicates reduced pressure on the Cakalang fish in Bitung fishing ground.

The reduced fishing fleet in fisheries management area causes the industry to experience a shortage of raw materials. However, Mulatsih (2009) suggested that Bitung City is the largest industrial city in North Sulawesi.

Based on the description above, it is assumed that the reduction of ships operating would reduce fishing pressure. This research examined the bio-ecology of Cakalang fish on the Bitung City fishing ground before and after the moratorium. follows:

Based on the description above, the formulation of the problems is described as

- What is the exploitation rate of Cakalang fish (Katsuwonus pelamis) in the Fisheries Management Area 714?

- What is the exploitation rate of Cakalang fish (Katsuwonus pelamis) in the Fisheries Management Area 715 ?

- What is the exploitation rate of Cakalang fish (Katsuwonus pelamis) in the Fisheries Management Area 716?

Based on the problem formulation above, the purpose of this study is described follows:

1. To assess the exploitation rate of Cakalang fish (Katsuwonus pelamis) in the Fisheries Management Area 714;

2. To assess the exploitation rate of Cakalang fish (Katsuwonus pelamis) in the Fisheries Management Area 715;

3. To assess the exploitation rate of Cakalang fish (Katsuwonus pelamis) in the Fisheries Management Area 716.

\section{METHODS OF RESEARCH}

This research was conducted from August to November 2018 in Bitung fishing bases. The fishing bases are located in Bitung PPS (Port of Ocean Fisheries), covering fishing ground FMA 714, FMA 715, and FMA 716.

Bitung is located in $1^{\circ} 23^{\prime} 23^{\prime \prime}$ - $1^{\circ} 35^{\prime} 39^{\prime \prime}$ LU and $125^{\circ} 1^{\prime} 43^{\prime \prime}$ - 125 $15^{\prime} 13^{\prime \prime}$ BT, with the following borders:

- North borders Likupang District, North Minahasa Regency;

- East borders Maluku Sea;

- South borders Maluku Sea;

- West borders Kauditan District, North Minahasa Regency.

The observation locations for bio-ecology are fisheries management area 714 (FMA 714) Banda sea and Tolo bay, fisheries management area 715 (FMA 715) Tomini Bay and Seram sea, Berau sea, Halmahera sea, and Maluku sea, and fisheries management area 716 (FMA 716) Sulawesi Sea and North Halmahera. 


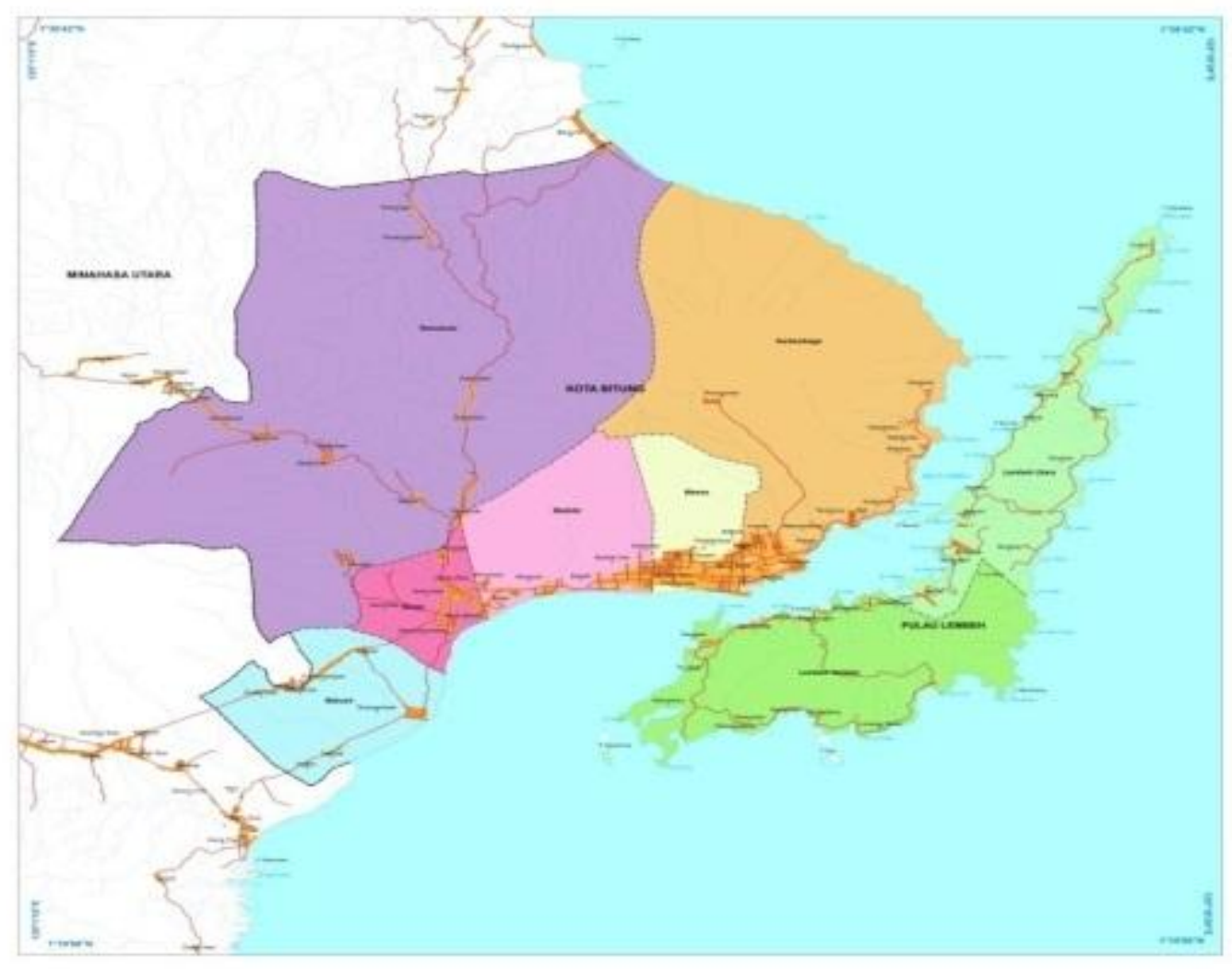

Figure 1 - Research Location

The composition of Cakalang fish was observed by measuring the Cakalang fish caught by fishermen from three FMAs, namely FMA 714, FMA 715, and FMA 716 in Bitung PPS fishing base. Structure measurement of Cakalang fish size was conducted by measuring the fork length $(\mathrm{cm})$.

NORMSEP (Normal Sepation) method in the FISAT II (FAO-ICLARM Fish Stock ASSESMENT Tool) program was utilized for this purpose.

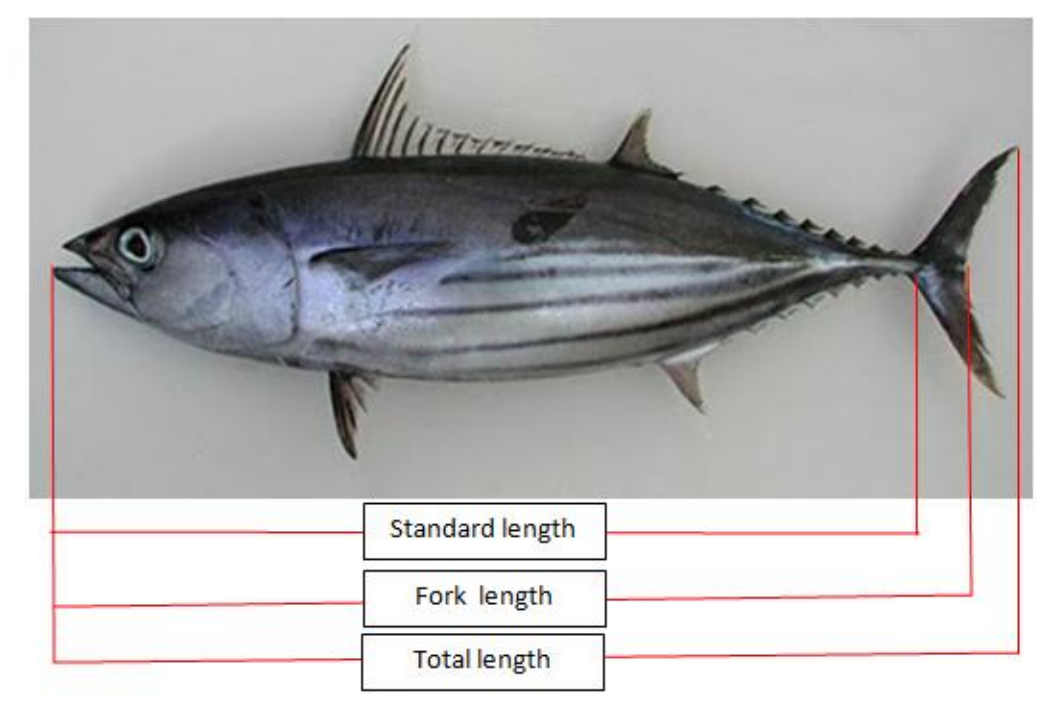

Figure 2 - Fish length measurement methods. Standard length (SL), fork length (FL), and total length (TL) 
Samples of Cakalang fish length were caught using fishing gear in FMA 714, FMA 715, and FMA 716. Cakalang fish size groups are separated using the Bhattacharya method. The Bhattacharya method is a method of separating age groups graphically.

To determine the growth parameters, this study used the Cakalang fish sample length. The fish were caught in FMA 714, FMA 715, and FMA 716 Bitung fishing ground.

The total mortality rate (Z) was estimated using the Jones \& Van Zalinge method through the FiSAT II program. To estimate the natural mortality rate (M), the researcher used the Pauly empirical formula (1984). The formula is used to calculate the type of fish that has a clustered habit. It is multiplied by 0.8 . Therefore clustered species such as Cakalang fish possess $20 \%$ lower estimation value.

$$
\begin{gathered}
\ln \mathrm{M}=-0,0152-0,279 \ln L_{\mathrm{os}}+0,6543 \ln \mathrm{K}+0,463 \ln \mathrm{T} \\
\mathrm{M}=0,8 \mathrm{e}^{(\mathrm{lnM})}
\end{gathered}
$$

Where: $M=$ natural mortality; $L^{\infty}=$ asymptotic length in the von Bertalanffy growth equation; $\mathrm{K}=$ growth coefficient on the von Bertalanffy growth equation; $\mathrm{T}=$ average water surface temperature $\left({ }^{\circ} \mathrm{C}\right)$.

Catch mortality rate $(F)$ is determined by:

$$
\mathrm{F}=\mathrm{Z}-\mathrm{M}
$$

The exploitation rate $(E)$ is determined by comparing the rate of catch mortality $(F)$ to total mortality (Z)(Pauly, 1984):

$$
\mathrm{E}=\frac{F}{F+M}=\frac{F}{Z}
$$

Where: $\mathrm{F}=$ Catch mortality; $\mathrm{Z}=$ total mortality; $\mathrm{M}=$ natural mortality.

The type of data in this study used quantitative data, namely the length of Cakalang fish in the fishing ground FMA 714,715 and 716.

Sources of data in the study are Primary data in the form of length of Cakalang fish caught in FMA 714,715, and 716 from fishing vessels in Bitung PPS and fishing companies.

Table 1 - The Total Data in FMA 714,715, and 716 before and after the moratorium

\begin{tabular}{|c|c|c|c|c|c|}
\hline \multicolumn{3}{|c|}{ Total Data Before Moratorium } & \multicolumn{3}{c|}{ Total Data After Moratorium } \\
\hline FMA 714 & FMA 715 & FMA 716 & FMA 714 & FMA 715 & FMA 716 \\
\hline 7202 & 58802 & 6902 & 282591 & 2191990 & 276201 \\
\hline
\end{tabular}

To achieve the research objectives, FISAT II data analysis was carried out.

\section{RESULTS AND DISCUSSION}

Based on the decree of the Minister of Marine Affairs and Fisheries number 18 / Kepmen-KP / 2014 concerning the area of Indonesian fisheries management, FMA 714 covers the Tolo bay and the Banda Sea.

t FMA 714 natural mortality was 0.97 before the moratorium and 0.96 after the moratorium. The catch mortality was 1.62 before the moratorium and 0.89 after the moratorium. Total mortality $(\mathrm{Z})$ was 2.56 before the moratorium and 1.65 after the moratorium.

The exploitation rate on FMA 714 was 0.65 before the moratorium and 0.54 after the moratorium. 
Based on the decree of the Minister of Marine Affairs and Fisheries number 18 / Kepmen-KP / 2014 concerning the territory of Indonesian fisheries management, FMA 715 covers the Maluku and Halmahera seas.

FMA 715 natural mortality was 0.89 before the moratorium and 0.53 after the moratorium. The mortality rate was 1.95 before the moratorium and 1.06 after the moratorium. The total mortality before the moratorium was 2.67 and 1.60 after the moratorium.

The exploitation rate on FMA 715 was 0.69 before the moratorium and 0.57 after the moratorium.

Based on the decree of the Minister of Marine Affairs and Fisheries number 18 / Kepmen-KP / 2014 concerning the area of Indonesian fisheries management, FMA 716 covers Sulawesi sea waters.

Natural mortality at FMA 716 was 0.99 before the moratorium and 0.76 after the moratorium. Catch mortality was 1.50 before the moratorium and 0.89 after the moratorium. Total mortality was 2.49 before the moratorium and 1.65 after the moratorium.

The exploitation rate on FMA 716 was 0.60 before the moratorium and 0.54 after the moratorium.

According to Gulland (1971), $E>0.5, F>M$ indicate over fishing. $E=0.5, M=F$ exhibits Maximum Sustainable Yield (MSY). $\mathrm{E}<0.5, \mathrm{~F}<\mathrm{M}$, indicates under fishing.

Based on the FISAT II analysis result, FMA 714 and 716 exhibits relatively overfishing before the moratorium. However, it exhibited MSY after the moratorium. FMA 715 exhibits overfishing before and after the moratorium. Nevertheless, there has been a significant decrease from 0.69 to 0.57 .

\section{CONCLUSION AND SUGGESTIONS}

The catch exploitation rate in FMA 714 are $\mathrm{E}=0.63$ before the moratorium and $\mathrm{E}=0.54$ after the moratorium.

The catch exploitation rate in FMA 715 are $E=0.69$ before the moratorium and $\mathrm{E}=0.57$ after the moratorium.

The catch exploitation rate in FMA 716 are $E=0.60$ before the moratorium and $\mathrm{E}=0.54$ after the moratorium.

Further research on socio-economic conditions before and after the moratorium is necessary. A comprehensive study of government policy on exploitation in other areas of fisheries management is necessary.

\section{REFERENCES}

1. Amiruddin.1993. Analisis Biologi ikan Cakalang di laut Flores. Tesis UNHAS. Makassar

2. Effendie I.1997. Biologi Perikanan. Yayasan Pustaka Nusatama. Yogyakarta.

3. FAO.1983.Living Marine Resources and Their Fish Sustainable Development. Fisheries Technical Paper. Rome.

4. Gunarso.1985.Tingkah Laku Ikan Dalam Hubungan Dengan Hubungannya and Taktik Penangkapan.Jurusan Pemanfaatan Sumberdaya Perikanan.Fakultas Perikanan.IPB Bogor.149 hal.

5. Jamal,M.2011. Analisis Perikanan Cakalang (Katsuwonus pelamis) di Teluk Bone: Hubungan Aspek Biologi and Faktor Lingkungan.Disertasi. Pascarjana IPB.Bogor.252 hlm.

6. Kementerian Kelautan and Perikanan. 2012.Usaha Perikanan Tangkap di Wilayah Pengelolaan Perikanan Negara Republik Indonesia.PERMEN KP nomor PER 30/MEN/2012.

7. Kementerian Kelautan and Perikanan.2013. Perubahan atas Peraturan Menteri Kelautan and Perikanan Nomor PER 30/men/2012. Usaha Perikanan Tangkap di Wilayah Pengelolaan Perikanan Negara Republik Indonesia. PERMEN KP Nomor 26/PERMENKP/2013. 
8. Kementerian Kelautan and Perikanan. 2014. Penghentian Sementara (Moratorium) Perizinan Tangkap di Wilayah Pengelolaan Perikanan Negara Republik Indonesia. PERMEN KP Nomor 56/PERMEN-KP/2014.

9. Kementerian Kelautan and Perikanan.2014. Perubahan Kedua atas Peraturan Menteri Kelautan and Perikanan Nomor PER.30/MEN/2012 tentang Usaha Perikanan Tangkap di Wilayah Pengelolaan Perikanan Negara Republik Indonesia.

10. Kementerian Kelautan and Perikanan.2014.Wilayah Pengelolaan Perikanan Republik Indonesia. PERMEN KP Nomor 18/PERMEN-KP/2014.

11. Manik.N.2007. Beberapa Aspek Biologi Ikan Cakalang (Katsuwonus pelamis) di Perairan Sekitar Pulau Seram Selatan and Pulau Nusa Laut. Jurnal Oseanologi and Limnologi di 33: $17-25$. ISSN $0125-9830$.

12. Merta S.G.I. 1982. Studi pendahuluan makanan tingkat kematangan gonad ikan Cakalang, Katsuwonus pelamis (LINN.1758), dari perairan sebelah Selatan Bali and sebelah Barat Sumatera. Jur. Pen. Per. Laut 26: 69 - 74.

13. Pelabuhan Perikanan Samudra Bitung.2017. Laporan Penerbitan Izin Berlayar Di Pelabuhan Samudera Bitung. 